\title{
Controlling Johne's disease: vaccination is the way forward
}

\author{
John P. Bannantine ${ }^{1 *}$ and Adel M. Talaat ${ }^{2}$ \\ ${ }^{1}$ Infectious Bacterial Diseases, National Animal Disease Center, United States Department of Agriculture - Agricultural Research Service, Ames, IA, USA \\ 2 Department of Pathobiological Sciences, University of Wisconsin, Madison, WI, USA \\ ${ }^{*}$ Correspondence: john.bannantine@ars.usda.gov
}

Edited and reviewed by:

Yousef Abu Kwaik, University of Louisville School of Medicine, USA

Keywords: Johne's disease, vaccines, Mycobacterium, paratuberculosis, veterinary medicine

M. avium subspecies paratuberculosis, hereafter referred to as $M A P$, is a significant veterinary pathogen that causes Johne's disease in ruminants, including cattle, sheep, and goats. This chronic intestinal disease is distributed worldwide and exacts a heavy economic toll on animal producers. For example, the dairy industry incurs substantial economic losses due to reduced milk production, premature culling, and reduced slaughter value (Raizman et al., 2009). It takes years for clinical signs to appear in animals after initial infection. The bacterium is shed in high numbers in the feces during this clinical phase of disease. Transmission is by ingestion of the bacterium while grazing on pastures contaminated by this shedding process. Milk, passed from the infected dam to the daughter, has also been shown as a transmission route (Stabel, 2008). To best combat this chronic infection, vaccination has the promise to reduce economic losses and control Johne's disease. In the conception of this eBook for Frontiers in Cellular and Infection Microbiology, we solicited communications describing technologies and approaches to immunize animals against Johne's disease.

Among the first large-scale vaccine trials for Johne's disease began in the early 1990s using killed whole cells in oil injected into cattle (Kormendy, 1994; Wentink et al., 1994). Those trials showed vaccination was useful to reduce shedding of the bacteria in the feces, thus potentially reducing cow-to-calf transmission, but was ineffective at preventing infection. Since that time, experiments have evaluated extracts of the bacteria and live cells in all hosts including sheep, goats, deer, and cattle. Furthermore, the strain of MAP used has varied greatly in those studies. Then in 2007, an effort was made to standardize the challenge models used to test new vaccines for combating Johne's disease (Hines et al., 2007). The parameters outlined for the goat model in that article were used to test the best available live attenuated candidates (Hines et al., 2014) as described in this eBook compilation.

The genome sequence and re-sequence of MAP ( $\mathrm{Li}$ et al., 2005; Wynne et al., 2010) has greatly expanded our knowledge about proteins predicted to be located in the mycobacterial envelope through annotation and bioinformatic analyses. Even now, most of what is known can be obtained only from annotation predictions and computer modeling algorithms that suggest protein locations within a cell (Yu et al., 2010). A perfect example of the power of genomics was demonstrated a few years later when libraries of transposon mutants and transcriptomic studies were reported by several groups working with MAP (Shin et al., 2006; Wu et al., 2006, 2007; Janagama et al., 2010). Furthermore, genomics provided an important resource for targeted construction of live-attenuated vaccine (LAV) candidates, which is the focus of several articles in this eBook. It is noteworthy that despite a focus on LAV strategies, we do not discount efforts directed toward the development of other vaccine technologies such as subunit or vectored vaccines (Hoek et al., 2010; Faisal et al., 2013; Thakur et al., 2013). Although these technologies are still under development, they could provide effective vaccines in the future.

Live attenuated vaccine strains of MAP are thought to be the best approach for vaccination against Johne's disease. Although traditional inactivated and LAV candidates cannot satisfy the DIVA approach, they will completely stimulate both cell-mediated and humoral immune responses (Park et al., 2011; Faisal et al., 2013). Numerous studies have suggested the role of cell-mediated immunity to provide protective responses against MAP infection, as suggested before in both the murine (Ghosh et al., 2014; Settles et al., 2014) and bovine models (Stabel et al., 2011) of Johne's disease. A partial analysis of the generated immune responses following immunization with novel LAV candidates is reported in this eBook (Hines et al., 2014) as part of a large scale vaccine trial. Additional analyses on the $\mathrm{T}$ cell populations and specific antigens detected will be forthcoming (Bannantine et al., unpublished).

To summarize the contributions to this research topic, the opening article reviews efforts by the Johne's disease research community to test available LAV strains of MAP through a series of three gated trials (Bannantine et al., 2014b). This trial series has been a coordinated international, multi-institutional effort that spanned several years. Many new ideas and retrospective approaches have emerged from this unprecedented effort. These aspects have been captured in this research topic. Details surrounding the construction of the attenuated mutants are also included as well as a list of the lessons learned from this integrated study. The next two articles describe a knockout mutant of relA (Park et al., 2014) and a library of transposon mutants (Rathnaiah et al., 2014). Both approaches are useful for generating live attenuated strains. The next three articles (Bannantine et al., 2014a; Hines et al., 2014; Lamont et al., 2014) describe in detail the three phases of the vaccine project summarized in the opening article. The remaining articles highlight immunological evaluation of subunit vaccines (Gurung et al., 2014), production of subunit vaccines using heterologous hosts (Johnston et al., 2014) and finally, take a unique look at the importance of post-translational modifications for vaccine design, with a highlight on glycoproteins (Facciuolo and Mutharia, 2014). 


\section{REFERENCES}

Bannantine, J. P., Everman, J. L., Rose, S. J., Babrak, L., Katani, R., Barletta, R. G., et al. (2014a). Evaluation of eight live attenuated vaccine candidates for protection against challenge with virulent Mycobacterium avium subspecies paratuberculosis in mice. Front. Cell. Infect. Microbiol. 4:88. doi: 10.3389/fcimb. 2014.00088

Bannantine, J. P., Hines, M. E. II, Bermudez, L. E., Talaat, A. M., Sreevatsan, S., Stabel, J. R., et al. (2014b). A rational framework for evaluating the next generation of vaccines against Mycobacterium avium subspecies paratuberculosis. Front. Cell. Infect. Microbiol. 4:126. doi: 10.3389/fcimb.2014.00126

Facciuolo, A., and Mutharia, L. M. (2014). Mycobacterial glycoproteins: a novel subset of vaccine candidates. Front. Cell. Infect. Microbiol. 4:133. doi: 10.3389/fcimb.2014.00133

Faisal, S. M., Yan, F., Chen, T. T., Useh, N. M., Guo, S., Yan, W., et al. (2013). Evaluation of a Salmonella vectored vaccine expressing Mycobacterium avium subsp. paratuberculosis antigens against challenge in a goat model. PLoS ONE 8:e70171. doi: 10.1371/journal.pone.0070171

Ghosh, P., Steinberg, H., and Talaat, A. M. (2014). Virulence and immunity orchestrated by the global gene regulator sigL in Mycobacterium avium subsp. paratuberculosis. Infect. Immun. 82, 3066-3075. doi: 10.1128/IAI.00001-14

Gurung, R. B., Purdie, A. C., Whittington, R. J., and Begg, D. J. (2014). Cellular and humoral immune responses in sheep vaccinated with candidate antigens MAP2698c and MAP3567 from Mycobacterium avium subspecies paratuberculosis. Front. Cell. Infect. Microbiol. 4:93. doi: 10.3389/fcimb.2014.00093

Hines, M. E. II, Stabel, J. R., Sweeney, R. W., Griffin, F., Talaat, A. M., Bakker, D., et al. (2007). Experimental challenge models for Johne's disease: a review and proposed international guidelines. Vet. Microbiol. 122, 197-222. doi: 10.1016/j.vetmic.2007.03.009

Hines, M. E. II, Turnquist, S. E., Ilha, M. R. S., Rajeev, S., Jones, A. L., Whittington, L., et al. (2014). Evaluation of novel oral vaccine candidates and validation of a caprine model of Johne's disease. Front. Cell. Infect. Microbiol. 4:26. doi: 10.3389/fcimb.2014.00026

Hoek, A., Rutten, V. P., van der Zee, R., Davies, C. J., and Koets, A. P. (2010). Epitopes of Mycobacterium avium ssp. paratuberculosis $70 \mathrm{kDa}$ heat-shock protein activate bovine helper T cells in outbred cattle. Vaccine 28, 5910-5919. doi: 10.1016/j.vaccine.2010.06.042

Janagama, H. K., Lamont, E. A., George, S., Bannantine, J. P., Xu, W. W., Tu, Z. J., et al. (2010). Primary transcriptomes of Mycobacterium avium subsp. paratuberculosis reveal proprietary pathways in tissue and macrophages. BMC Genomics 11:561. doi: 10.1186/1471-2164-11-561

Johnston, C. D., Bannantine, J. P., Govender, R., Endersen, L., Pletzer, D., Weingart, H., et al. (2014). Enhanced expression of codon optimized Mycobacterium avium subsp. paratuberculosis antigens in Lactobacillus salivarius. Front. Cell. Infect. Microbiol. 4:120. doi: 10.3389/fcimb.2014.00120

Kormendy, B. (1994). The effect of vaccination on the prevalence of paratuberculosis in large dairy herds. Vet. Microbiol. 41, 117-125. doi: 10.1016/03781135(94)90141-4

Lamont, E. A., Talaat, A. M., Coussens, P. M., Bannantine, J. P., Grohn, Y. T., Katani, R., et al. (2014). Screening of Mycobacterium avium subsp. paratuberculosis mutants for attenuation in a bovine monocyte-derived macrophage model. Front. Cell. Infect. Microbiol. 4:87. doi: 10.3389/fcimb.2014.00087

Li, L., Bannantine, J. P., Zhang, Q., Amonsin, A., May, B. J., Alt, D., et al. (2005). The complete genome sequence of Mycobacterium avium subspecies paratuberculosis. Proc. Natl. Acad. Sci. U.S.A. 102, 12344-12349. doi: 10.1073/pnas.0505662102

Park, K. T., Allen, A. J., Bannantine, J. P., Seo, K. S., Hamilton, M. J., Abdellrazeq, G. S., et al. (2011). Evaluation of two mutants of Mycobacterium avium subsp. paratuberculosis as candidates for a live attenuated vaccine for Johne's disease. Vaccine 29, 4709-4719. doi: 10.1016/j.vaccine.2011.04.090

Park, K. T., Allen, A. J., Barrington, G. M., and Davis, W. C. (2014). Deletion of relA abrogates the capacity of Mycobacterium avium paratuberculosis to establish an infection in calves. Front. Cell. Infect. Microbiol. 4:64. doi: $10.3389 /$ fcimb. 2014.00064
Raizman, E. A., Fetrow, J. P., and Wells, S. J. (2009). Loss of income from cows shedding Mycobacterium avium subspecies paratuberculosis prior to calving compared with cows not shedding the organism on two Minnesota dairy farms. J. Dairy Sci. 92, 4929-4936. doi: 10.3168/jds.2009-2133

Rathnaiah, G., Lamont, E. A., Harris, N. B., Fenton, R. J., Zinniel, D. K., Liu, X., et al. (2014). Generation and screening of a comprehensive Mycobacterium avium subsp. paratuberculosis transposon mutant bank. Front. Cell. Infect. Microbiol. 4:144. doi: 10.3389/fcimb.2014.00144

Settles, E. W., Kink, J. A., and Talaat, A. (2014). Attenuated strains of Mycobacterium avium subspecies paratuberculosis as vaccine candidates against Johne's disease. Vaccine 32, 2062-2069. doi: 10.1016/j.vaccine.2014.02.010

Shin, S. J., Wu, C. W., Steinberg, H., and Talaat, A. M. (2006). Identification of novel virulence determinants in Mycobacterium paratuberculosis by screening a library of insertional mutants. Infect. Immun. 74, 3825-3833. doi: 10.1128/IAI. 01742-05

Stabel, J. R. (2008). Pasteurization of colostrum reduces the incidence of paratuberculosis in neonatal dairy calves. J. Dairy Sci. 91, 3600-3606. doi: 10.3168/jds.2008-1107

Stabel, J. R., Waters, W. R., Bannantine, J. P., and Lyashchenko, K. (2011). Mediation of host immune responses after immunization of neonatal calves with a heat-killed Mycobacterium avium subsp. paratuberculosis vaccine. Clin. Vaccine Immunol. 18, 2079-2089. doi: 10.1128/CVI.05421-11

Thakur, A., Aagaard, C., Stockmarr, A., Andersen, P., and Jungersen, G. (2013). Cell-mediated and humoral immune responses after immunization of calves with a recombinant multiantigenic Mycobacterium avium subsp. paratuberculosis subunit vaccine at different ages. Clin. Vaccine Immunol. 20, 551-558. doi: 10.1128/CVI.05574-11

Wentink, G. H., Bongers, J. H., Zeeuwen, A. A., and Jaartsveld, F. H. (1994). Incidence of paratuberculosis after vaccination against $M$. paratuberculosis in two infected dairy herds. Zentralbl. Veterinarmed. B 41, 517-522.

Wu, C. W., Glasner, J., Collins, M., Naser, S., and Talaat, A. M. (2006). Whole-genome plasticity among Mycobacterium avium subspecies: insights from comparative genomic hybridizations. J. Bacteriol. 188, 711-723. doi: 10.1128/JB.188.2.711-723.2006

Wu, C. W., Schmoller, S. K., Shin, S. J., and Talaat, A. M. (2007). Defining the stressome of Mycobacterium avium subsp. paratuberculosis in vitro and in naturally infected cows. J. Bacteriol. 189, 7877-7886. doi: 10.1128/JB.00780-07

Wynne, J. W., Seemann, T., Bulach, D. M., Coutts, S. A., Talaat, A. M., and Michalski, W. P. (2010). Resequencing the Mycobacterium avium subsp. paratuberculosis K10 genome: improved annotation and revised genome sequence. J. Bacteriol. 192, 6319-6320. doi: 10.1128/JB.00972-10

Yu, N. Y., Wagner, J. R., Laird, M. R., Melli, G., Rey, S., Lo, R., et al. (2010). PSORTb 3.0: improved protein subcellular localization prediction with refined localization subcategories and predictive capabilities for all prokaryotes. Bioinformatics 26, 1608-1615. doi: 10.1093/bioinformatics/btq249

Conflict of Interest Statement: The authors declare that the research was conducted in the absence of any commercial or financial relationships that could be construed as a potential conflict of interest.

Received: 19 December 2014; accepted: 05 January 2015; published online: 21 January 2015.

Citation: Bannantine JP and Talaat AM (2015) Controlling Johne's disease: vaccination is the way forward. Front. Cell. Infect. Microbiol. 5:2. doi: 10.3389/fcimb. 2015.00002

This article was submitted to the journal Frontiers in Cellular and Infection Microbiology.

Copyright (c) 2015 Bannantine and Talaat. This is an open-access article distributed under the terms of the Creative Commons Attribution License (CC BY). The use, distribution or reproduction in other forums is permitted, provided the original author(s) or licensor are credited and that the original publication in this journal is cited, in accordance with accepted academic practice. No use, distribution or reproduction is permitted which does not comply with these terms. 